http://www.nauka-a-religia.uz.zgora.pl/images/FAG/2009-2010.t.6-7/art.11.pdf

\author{
Stephen C. Meyer
}

\title{
Demarkacja nauki i religii *
}

\section{Wprowadzenie}

Czym jest nauka? Czym jest religia? Jaka zachodzi między nimi relacja? Historycy nauki stawiają te pytania, analizując, w jaki sposób, w danym czasie wzajemnie na siebie oddziałują przekonania naukowe i religijne poszczególnych naukowców lub kultur. Filozofowie nauki i religii usiłują natomiast opisać stosunek pomiędzy nauką a religią za pomocą ogólniejszych kategorii. Wymaga to takiego ich zdefiniowania, by odróżniały lub „odgraniczały” je ostre i obiektywne kryteria. Współcześnie, na podstawie różnych definicji, teologowie i filozofowie nauki próbują dokonać wyraźnych rozgraniczeń między nauką a religią.

\section{Definiowanie różnic: kontekst filozoficzny}

Neoortodoksyjny teolog Karl Barth (1886-1968) podkreślał, że nauka i religia mają inne przedmioty zainteresowania. Religia i teologia

\footnotetext{
"Stephen C. Meyer, „The Demarcation of Science and Religion”, w: Gary B. Ferngren (ed.), The History of Science and Religion in the Western Tradition: An Encyclopedia, Garland Reference Library of the Humanities, vol. 1833, Garland Publishing, Inc., New York \& London 2000, s. 18-26, http://www.discovery.org/a/3524 (24.07.2009). Z języka angielskiego za zgodą Autora przełożyła Joanna PopeK. Recenzent: Krzysztof KiLıan, Zakład Ontologii i Teorii Poznania Uniwersytetu Zielonogórskiego.
} 
skupiają się na Objawieniu się Boga w Chrystusie. Nauka bada zaś świat przyrody. Barth twierdził, że nauka i religia używają innych metod zdobywania wiedzy. Naukowcy poznają świat zewnętrzny za pomocą rozumu i badań empirycznych. Grzech człowieka spowodował jednak, że ludzie nie mogą zdobyć wiedzy o Bogu dzięki widzialnemu świadectwu stworzenia, czyli na podstawie „Jego dzieł” - jak ujął to św. Paweł w Liście do Rzymian 1:20. Natomiast ludzka wiedza o Bogu pojawia się tylko wtedy, gdy On objawia się nam w sposób mistyczny lub aracjonalny.

Przedstawiciele filozofii egzystencjalnej, jak Søren Kierkegaard (1813-1855) i Martin Buber (1878-1965), również przyjmowali, że pomiędzy nauką a religią istnieje zasadnicza różnica epistemologiczna. Uznawali oni, że wiedza naukowa jest bezosobowa i obiektywna, natomiast wiedza religijna jest osobista i subiektywna. Wiedza obiektywna jest możliwa - przynajmniej jako ideał - ponieważ przedmiotem badań naukowych są obiekty materialne oraz ich funkcje. Religia zaś wymaga osobistego związku z poznawanym przedmiotem (Bogiem) i osobistej lub moralnej odpowiedzi Bogu. Sferę religijną cechuje więc skrajna subiektywność. Posiłkując się terminologią Bubera, wyrazić to można w następujący sposób: w nauce między poznającym a poznawanym zachodzi relacja „Ja-Ono”, zaś w religii - relacja „Ja-Ty”.

Grupa filozofów z początku dwudziestego wieku, znana jako logiczni pozytywiści, również obstawała przy tym, że nauka i religia to odrębne i rozłączne dziedziny. Wychodzili oni jednak od innych przesłanek. Według pozytywistów sensowne są tylko twierdzenia empirycznie weryfikowalne (lub logicznie niezaprzeczalne). Nauka formułuje twierdzenia o dających się zaobserwować bytach materialnych, a więc są one sensowne. Przekonania religijne lub metafizyczne odnoszą się natomiast do bytów nieobserwowalnych, jak Bóg, moralność, zbawienie, wolna wola i miłość. $Z$ definicji pozytywistów wynika, że przekonania religijne są pozbawione sensu. Jak wyjaśnił Frederick Copleston, głównym założeniem pozytywizmu była teza, że - skoro wy- 
łącznie doświadczenie stanowi podstawę wiedzy - „metoda naukowa jest jedynym środkiem uzyskiwania wiedzy w sensie właściwym”. ${ }^{1}$ Pozytywizm nie tylko odróżnia naukę od religii, ale zaprzecza jednocześnie, że przekonania religijne mają obiektywną podstawę.

\section{Modele interakcji: definiowanie spraw spornych}

Współcześni filozofowie nauki i religii powszechnie uznają, że dziedziny te istotnie reprezentują dwa odrębne typy ludzkiej aktywności. Większość uważa, że wymagają one odmiennych czynności, mają inne cele oraz różne przedmioty zainteresowania, badań lub szacunku. $\mathrm{Z}$ tego powodu pojawiły się sugestie, że nauka i religia zajmują albo całkowicie oddzielne „przedziały”, albo „komplementarne”, ale rozłączne obszary dyskursu i zainteresowań. Poglądy te ujęto w postaci dwóch modeli interakcji pomiędzy nauką a religią, które nazywane są - odpowiednio - modelem bezwzględnej oddzielności (kompartmentalizm) i modelem uzupełniania się (komplementaryzm). W myśl modelu bezwzględnej oddzielności, przypisywanego Barthowi, Kierkegaardowi i pozytywistom, nauka i religia z samej swej natury oferują odmienne typy opisów różnych aspektów rzeczywistości. Komplementaryzm (w postaci wyrażonej głównie przez neurobiologa Donalda M. Mackaya w latach siedemdziesiątych dwudziestego wieku ${ }^{2}$ ) głosi, że nauka i religia mogą niekiedy mówić o jednej i tej samej rzeczywistości, ale opisują ją w zupełnie inny, choć komplementarny sposób (czyli używają tzw. języków „niewspółmiernych”). Oba te modele wykluczają, że pomiędzy nauką a religią może istnieć bądź konflikt, bądź porozumienie. Właściwie pojmowana nauka nie może ani wspierać, ani podważać religii, ponieważ obie te dziedziny reprezentują oddziel-

\footnotetext{
${ }^{1}$ Frederick Copleston, Historia filozofii. Od Benthama do Russella, t. VIII, przeł. Bohdan Chwedeńczuk, Instytut Wydawniczy PAX, Warszawa 1989, s. 121.

${ }^{2}$ Por. Donald M. Mackay, „«Complementarity» in Scientific and Theological Thinking”, Zygon 1974, vol. 9, s. 225-244.
} 
ne i nieprzecinające się ze sobą płaszczyzny doświadczenia i wiedzy. Oba omawiane modele interakcji pomiędzy nauką a religią zakładają zatem metafizyczną czy religijną neutralność wszystkich teorii naukowych.

Tacy współcześni filozofowie, jak Alvin Plantinga, Roy Clouser i J.P. Moreland, zakwestionowali jednak ideę ścisłej separacji nauki i religii. ${ }^{3}$ Zwracają oni uwagę, że $\mathrm{z}$ faktu istnienia autentycznych różnic między tymi dziedzinami nie wynika, iż muszą się one różnić jakościowo pod każdym względem. Filozofowie zauważyli zatem, że zarówno nauka, jak religia formułują sądy prawdziwościowe. Co więcej, nauka i religia często przynajmniej zdają się wypowiadać na ten sam temat w jasnym, prepozycyjnym języku. Na przykład obie formułują sądy o początku i naturze Wszechświata czy pochodzeniu życia i człowieka. Obie mówią o naturze człowieka, historii poszczególnych kultur ludzkich i charakterze doświadczenia religijnego. Zarówno religia, jak i nauka mogą się w tych sprawach mylić, jednak niewielu współczesnych filozofów nauki (ale nie teologów czy naukowców) podziela pogląd, zgodnie z którym sądy prawdziwościowe nauki i religii nigdy się nie krzyżują. Zwłaszcza religie historyczne, takie jak judaizm, chrześcijaństwo i islam, formułują szczegółowe twierdzenia, dotyczące zdarzeń rozgrywających się w czasie i w przestrzeni, które mogą być sprzeczne lub zgodne z konkretnymi teoriami naukowymi.

Plantinga argumentuje, że wiele teorii naukowych (choć nie wszystkie) ma metafizyczne i religijne implikacje. Podaje on kilka przykładów teorii, które - jeśli traktuje się je jako mówiące coś na temat rzeczywistości, a nie tylko jako narzędzia, służące do porządkowania doświadczenia lub formułowania hipotez - zawierają ewidentne treści metafizyczne. Zauważa na przykład, że różnorodne kosmologiczne wyjaśnienia subtelnego zestrojenia stałych fizycznych (tzw. koincydencji ,antropicznych”) albo wspierają, albo zaprzeczają poglą-

\footnotetext{
${ }^{3}$ Por. Alvin Plantinga, „When Faith and Reason Clash: Evolution and the Bible”, Christian Scholar's Review 1991, vol. 21, no. 1, s. 8-32; Roy Clouser, The Myth of Religious Neutrality, Notre Dame University Press, Notre Dame, Indiana 1993; J.P. Moreland, Christianity and the Nature of Science, Baker Books, Grand Rapids, Michigan 1989.
} 
dom teistycznym, socjobiologia i teizm w skrajnie odmienny sposób wyjaśniają ludzki altruizm, zaś neodarwinowska teoria ewolucji, na przekór teizmowi, zaprzecza, by w świecie istniał możliwy do wykrycia projekt (lub cel). ${ }^{4}$

$\mathrm{Z}$ tą opinią Plantingi zgadza się wielu biologów ewolucyjnych. Francisco Ayala, Stephen Jay Gould, William Provine, Douglas Futuyma, Richard Dawkins, Richard Lewontin i nieżyjący już G.G. Simpson przyznają, że neodarwinizm (pojmowany jako realistyczne przedstawienie historii życia) przyjmuje wyłącznie przyrodniczy mechanizm stworzenia, w którym inteligencja nie gra żadnej roli. Jak wskazuje Simpson, ,człowiek jest rezultatem bezcelowego i przyrodniczego procesu, który nie miał go na myśli”. ${ }^{5}$ W odróżnieniu od klasycznego teizmu, tego typu teorie zaprzeczają istnieniu dostrzegalnych świadectw boskiego zamysłu, kierownictwa lub projektu w sferze biologicznej. $Z$ darwinowskiego punktu widzenia każdy przejaw projektu biologicznego jest po prostu złudzeniem. Zatem, nawet jeśli Bóg istnieje, to jego istnienie nie przejawia się w wytworach przyrody. Francisco Ayala wyjaśnia, że „Funkcjonalny projekt organizmów oraz ich cechy $[\ldots]$ zdają się przemawiać za istnieniem projektanta. Największym osiągnięciem Darwina było [jednak] wykazanie, że celowa organizacja istot żywych mogła powstać wskutek działania przyrodniczego procesu - selekcji naturalnej - i że w ogóle nie trzeba powoływać się na Stwórcę lub inną zewnętrzną przyczynę". ${ }^{6}$ Według Richarda Lewontina i wielu innych czołowych neodarwinistów organizmy żywe jedynie sprawiają „wrażenie” zaprojektowanych.

Stwierdzenia takie doskonale uzmysławiają, dlaczego próby ścisłego oddzielenia nauki od metafizyki lub nauki od religii spotykają się

\footnotetext{
${ }^{4}$ Por. Alvin Plantinga, „Methodological Naturalism”, Origins and Design 1996, vol. 18, no. 1 , s. $18-27$.

${ }^{5}$ George Gaylord Simpson, The Meaning of Evolution, Harvard University Press, Cambridge, Massachusetts 1967, s. 344-345.

${ }^{6}$ Francisco Ayala, w: John H. Campbell and J.W. Schoff (eds.), Creative Evolution!?, Jones and Bartlett, New York 1994, s. 4-5.
} 
z coraz większą krytyką. Jeżeli teorie naukowe oraz doktryny religijne traktuje się jako zbiory sądów prawdziwościowych (a zarówno naukowcy, jak i osoby religijne zwykle nadają im właśnie takie znaczenie), to niektóre teorie naukowe mogą zapewniać potwierdzenie doktrynom religijnym lub im przeczyć. W rzeczy samej, wielu utrzymywałoby, że nie ma powodu, aby wykluczyć możliwość, iż niektóre sądy prawdziwościowe religii mogą być racjonalnie oceniane na podstawie ogólnie dostępnych świadectw. Niektóre przytoczone wcześniej przykłady wskazują, że odkrycia lub teorie naukowe rzeczywiście mogą być sprzeczne z doktrynami religijnymi. Inne przykłady przemawiają natomiast za tym, że nauka może również potwierdzać sądy prawdziwościowe religii. Świadectwa archeologiczne mogą wspierać biblijne twierdzenia na temat historii Izraela lub początków chrześcijaństwa, świadectwa kosmologiczne lub biologiczne mogą przemawiać za różnymi teologicznymi koncepcjami stworzenia, zaś świadectwa neurofizjologiczne lub psychologiczne mogą potwierdzać wywodzące się z przekonań religijnych koncepcje świadomości i natury ludzkiej. Chociaż wiele osób religijnych uznaje za Barthem i Buberem, że wiara religijna wymaga czegoś więcej niż tylko intelektualnej akceptacji twierdzeń doktrynalnych, to jednak nie wynika $z$ tego, że owe twierdzenia nie mają podstaw empirycznych czy racjonalnych.

Wyniki ostatnich badań nad relacją między nauką a religią wskazują, że komplementaryzm i kompartmentalizm mają pewne ograniczenia. Mimo iż większość filozofów nauki i religii zgodziłaby się, że modele te trafnie opisują pewne aspekty wzajemnego stosunku nauki i religii, wielu twierdzi jednak, że nie ujmują one całej jego złożoności. Rzeczywisty konflikt i autentyczna zgodność pomiędzy naukowymi a religijnymi sądami prawdziwościowymi są możliwe i zdarzały się w historii. Teorie naukowe nie zawsze mogą zachowywać religijną lub metafizyczną neutralność.

Współcześni obrońcy komplementaryzmu zapewniają, że rzekome metafizyczne implikacje teorii naukowych to $\mathrm{w}$ istocie bezpodstawne lub nieuzasadnione ich rozszerzenia, które same nie wchodzą w zakres nauki. Twierdzą oni, iż takie przekonania, jak na przykład przytoczone 
wcześniej opinie na temat darwinizmu, same w sobie nie są naukowe, lecz mają charakter ,paranaukowej” refleksji o nauce lub pseudonaukowej ,apologetyki” naturalizmu filozoficznego. Tego typu refleksje mogą być wyrazem metafizycznych poglądów poszczególnych naukowców (na przykład Goulda czy Simpsona), ale nie jest to dowód, że z nauki rzeczywiście płyną jakieś implikacje metafizyczne.

Krytycy komplementaryzmu są natomiast zgodni, że twierdzenia Ayali czy Simpsona wynikają z przyjęcia konkretnej metafizyki i mogą nie mieć empirycznego potwierdzenia. Według nich nie wynika $z$ tego jednak, że proponowane przez Goulda lub Simpsona ujęcie darwinizmu jest błędne, ani że darwinizm nie jest teorią naukową. Wiele teorii naukowych odzwierciedla przekonania naukowców. Niektóre z tych przekonań mają słabe potwierdzenie empiryczne albo są zawodne. Ale czy koniecznie świadczy to o ich nienaukowości? Można zadać jeszcze bardziej podstawowe pytanie: czy teorie naukowe moga mieć implikacje metafizyczne? Jeśli nie, to dlaczego? Czy na przykład Darwin mógł sformułować naukową teorię, w myśl której organizmy żywe powstały w rezultacie działania wytacznie sił przyrodniczych, takich jak dobór naturalny i losowa zmienność? Czy jako naukowiec mógł odrzucać pogląd, że celowe działanie boskie odegrało sprawczą rolę w procesie tworzenia nowych gatunków? Wielu historyków nauki uznaje, że Darwin chciał wykluczyć sprawczą rolę Boga z teorii ewolucji i że alternatywne teorie rozwoju życia przyjmują coś wprost przeciwnego. Czy darwinizm jest zatem nienaukowy? Czy cała dziewiętnastowieczna, przeddarwinowska biologia była nienaukowa? Jeśli tak, to dlaczego? Czym dokładnie jest nauka?

\section{Historia problemu demarkacji}

Powyższe pytania prowadzą nieuchronnie do jednego z najbardziej dręczących zagadnień filozofii nauki - problemu demarkacji. Identyfikowanie teorii lub twierdzeń jako naukowych i odróżnianie ich od przekonań religijnych lub metafizycznych (które są czym innym niż 
praktyki lub obrzędy religijne) nie może obyć się bez zbioru kryteriów definiujących naukę. Ale co dokładnie sprawia, że teoria jest naukowa? W jaki sposób można wyróżniać teorie naukowe lub jak wyznaczyć linię demarkacyjną między nimi a teoriami pseudonaukowymi oraz przekonaniami metafizycznymi lub religijnymi? Czy w ogóle trzeba je odróżniać?

W słynnym artykule „Zgon problemu demarkacji” ${ }^{7}$ Larry Laudan wyjaśnił, że większość współczesnych filozofów nauki straciła cierpliwość do prób odróżnienia teorii naukowych od nienaukowych. Kryteria demarkacji (mające oddzielić prawdziwą naukę od pseudonauki, metafizyki i religii) odrzucano poprzez wskazanie licznych kontrprzykładów. Z wieloma teoriami obalonymi na podstawie świadectw empirycznych wiążą się te właśnie epistemiczne i metodologiczne cechy (na przykład testowalność, falsyfikowalność, powtarzalność i obserwowalność), które przypisuje się teoriom prawdziwie naukowym. $\mathrm{Z}$ kolei niektórym wysoko cenionym teoriom brakuje jednej lub więcej tych rzekomo koniecznych cech naukowości.

Laudan zauważył, że śladem Arystotelesa naukę odróżniano najpierw od nienauki na podstawie stopnia pewności towarzyszącego wiedzy naukowej. Naukę, jak sądzono, można odróżnić od nienauki, ponieważ ta pierwsza prowadzi do wiedzy pewnej (episteme), podczas gdy rezultatem innego rodzaju dociekań, na przykład filozoficznych czy teologicznych, jest co najwyżej mniemanie (doxa). Jednak takie podejście do problemu demarkacji napotykało trudności. W przeciwieństwie do matematyków, przyrodnicy rzadko uzasadniają teorie w sposób ściśle logiczny (czyli przeprowadzając dowód dedukcyjny). W argumentacji naukowej często stosuje się natomiast wnioskowanie indukcyjne i sprawdza się przewidywania, a te metody nie prowadzą do wniosków pewnych. Co więcej, już filozofowie i naukowcy średniowieczni mieli pełną świadomość tych ograniczeń. Na przykład

\footnotetext{
${ }^{7}$ Larry Laudan, „Zgon problemu demarkacji”, przeł. Artur Koterski, w: Zbysław MusZYŃSKI (red.), Z badań nad prawdą, nauką i poznaniem, Realizm, Racjonalność, Relatywizm, t. 31, Wydawnictwo Uniwersytetu Marii Curie-Skłodowskiej, Lublin 1998, s. 63-79.
} 
William Ockham (ok. 1280-ok. 1349) i Duns Szkot (ok. 1265-ok. 1308) udoskonalili arystotelesowską logikę indukcyjną właśnie po to, by zminimalizować (choć nie wyeliminować) zawodność indukcji. Jak ponadto przekonuje Owen Gingerich, jedną z przyczyn konfliktu Galileusza z kościołem rzymskokatolickim było sprzeniewierzenie się scholastycznym standardom pewności dedukcyjnej, które Galileusz uważał za nieistotne i nieosiągalne w rozumowaniu naukowym. Pod koniec średniowiecza, a już na pewno w okresie rewolucji naukowej, uczeni i filozofowie rozumieli, że wiedza naukowa, podobnie jak każdy inny rodzaj wiedzy, nie prowadzi do wniosków pewnych. ${ }^{* *}$ Odtąd próby odróżnienia nauki od nienauki nabrały innego charakteru. Demarkacjoniści nie próbowali już charakteryzować nauki na podstawie wyższego statusu poznawczego teorii naukowych; próbowali robić to na podstawie lepszych metod, jakich nauka używa do tworzenia teorii. Naukę zaczęto definiować powołując się na jej metodę, a nie na jej pewność czy jej treść.

Takie podejście również napotkało jednak trudności. Jedną z nich jest konsekwentna rozbieżność opinii na temat tego, czym właściwie jest metoda naukowa. W siedemnastym wieku tzw. filozofowie mechanistyczni, w przeciwieństwie do arystotelików, upierali się przy tym, że teorie naukowe muszą wyjaśniać w sposób mechanistyczny. A jednak Izaak Newton (1642-1727) sformułował teorię, która takich wyjaśnień nie dostarczała. Jego teoria powszechnego ciążenia opisywała matematycznie grawitacyjny ruch planet, ale go nie wyjaśniała. Pomimo krytyki Gottfrieda Wilhelma Leibniza (1646-1716), który bronił ideału mechanistycznego, Newton kategorycznie odmówił podania jakiegokolwiek wyjaśnienia tajemniczego „oddziaływania na odległość”, występującego w jego teorii przyciągania grawitacyjnego.

Podobne spory na temat metody naukowej miały miejsce w wieku dziewiętnastym. Niektórzy naukowcy i filozofowie uważali procedury indukcyjne Johna Stuarta Milla (1806-1873) i Williama Herschela

\footnotetext{
** (Przyp. red.) Według Laudana (por. LAUDAN, „Zgon problemu demarkacji...”, s. 66-67) porzucenie ideału pewności nastąpiło dopiero w XIX wieku.
} 
(1738-1822) za reprezentatywną, prawdziwą metodę naukową. Inni głosili, że w nauce ideałem jest vera causa, co oznacza, że naukowcy powinni powoływać się na przyczyny znane lub możliwe do zaobserwowania. Jeszcze inni, jak C.S. Peirce (1839-1914) i William Whewell (1794-1866), podkreślali, że najważniejszą cechą charakterystyczną prawdziwej nauki jest sukces predykcyjny, przy czym nie ma znaczenia, czy przedmioty teoretyczne można zaobserwować bezpośrednio. Peirce i Whewell uważali także, że w pewnych sytuacjach teorie naukowe cechuje nie sukces predykcyjny, lecz moc eksplanacyjna. Ten brak zgodności prowadził do zamieszania w szeregach demarkacjonistów. Jeżeli naukowcy i filozofowie nie są jednomyślni co do tego, czym jest metoda naukowa, to jak mogą odróżniać naukę od dyscyplin, do których nie można zastosować tego terminu? Tak czy owak, może istnieć więcej metod naukowych niż jedna. Na przykład w naukach historycznych stosuje się charakterystyczne typy wyjaśnień, wnioskowań i sposobów testowania. Jeśli istnieje więcej metod naukowych niż jedna, to próby oddzielenia nauki od nienauki za pomocą jednego zestawu kryteriów metodologicznych niemal na pewno skazane są na porażkę.

Narastające problemy związane z wprowadzeniem rozważań metodologicznych w życie, spowodowały kolejną zmianę kierunku przedsięwzięcia demarkacjonistycznego. Począwszy od lat dwudziestych minionego wieku, filozofia nauki zwróciła się w stronę lingwistyki czy semantyki. Zgodnie z logicznym pozytywizmem teorie naukowe można odróżnić od teorii nienaukowych nie dlatego, że te pierwsze formułuje się przy użyciu unikatowych czy lepszych metod, lecz $\mathrm{z}$ tego powodu, iż są one bardziej sensowne. Logiczni pozytywiści podkreślali, że wszystkie sensowne twierdzenia są albo empirycznie weryfikowalne, albo logicznie niezaprzeczalne. Zgodnie z tym ,weryfikacjonistycznym kryterium sensowności” teorie naukowe są bardziej sensowne od przekonań filozoficznych czy religijnych, ponieważ odnoszą się do przedmiotów obserwowalnych, podczas gdy filozofia i religia mówią o przedmiotach nieobserwowalnych. Takie ujęcie rów- 
nież subtelnie daje do zrozumienia, że przekonania metafizyczne są gorsze od teorii naukowych.

Pozytywizm uległ ostatecznie autodestrukcji. Filozofowie uświadomili sobie, że nie spełnia on własnego weryfikacjonistycznego kryterium sensowności: kryterium to nie jest ani empirycznie weryfikowalne, ani logicznie niezaprzeczalne. Pozytywizm błędnie ujmuje też praktykę naukową. Wiele aktualnie akceptowanych teorii naukowych mówi o niemożliwych do zweryfikowania i zaobserwowania przedmiotach, takich jak siły, pola, atomy, kwarki i prawa uniwersalne. Tymczasem wiele zdyskredytowanych teorii (na przykład teoria płaskiej Ziemi) odwołuje się wyłącznie do „zdroworozsądkowych” obserwacji. To oczywiste, że pozytywistyczne kryterium weryfikowalności nie stanowi takiego kryterium demarkacji, jakiego poszukują filozofowie nauki.

Wraz ze zgonem pozytywizmu demarkacjoniści przyjęli inną taktykę. Karl Popper (1902-1994) jako kryterium demarkacji zaproponował falsyfikowalność. Według Poppera teorie naukowe da się odróżnić od teorii metafizycznych, ponieważ te pierwsze można sfalsyfikować (ale nie zweryfikować) na podstawie przewidywań i obserwacji, natomiast w przypadku teorii metafizycznych jest to niemożliwe. Okazało się jednak, że to kryterium także jest problematyczne. Po pierwsze, nie jest łatwo dokonywać falsyfikacji. Rdzeń teorii naukowych rzadko można sprawdzić bezpośrednio na podstawie przewidywań. Przewidywania można formułować wtedy, gdy rdzeń teorii naukowych połączy się z hipotezami pomocniczymi, to natomiast zawsze pozostawia możliwość, że za błędność przewidywań odpowiada nie rdzeń, lecz właśnie hipotezy pomocnicze. Na przykład rdzeniem mechaniki newtonowskiej są trzy prawa ruchu oraz teoria powszechnego ciążenia. Bazując na tych założeniach, Newton sformułował wiele przewidywań, dotyczących położenia planet w Układzie Słonecznym. Kiedy jednak obserwacje nie potwierdziły prognoz Newtona, nie odrzucił on swoich podstawowych założeń. Zmodyfikował natomiast niektóre hipotezy pomocnicze, co pozwoliło mu wyjaśnić rozbieżność między teorią a obserwacjami. Skorygował na przykład robocze założenie, że plane- 
ty są idealnie kuliste i że wpływa na nie jedynie siła grawitacji. Jak wykazał Imre Lakatos, dzięki temu, że nawet w obliczu anomalii Newton nie odrzucił rdzenia swojej teorii, mógł ją udoskonalić i ostatecznie odniósł olbrzymi sukces. ${ }^{8}$ Eksplanacyjna elastyczność teorii Newtona nie świadczy o jej nienaukowości, jak sugerowałoby Popperowskie kryterium demarkacji.

Badania w dziedzinie historii nauki wykazały, że ideał falsyfikowalności nazbyt upraszcza rzeczywistość. Hipotezy pomocnicze sprawiają, że definitywne sfalsyfikowanie teorii (również tych, zaliczanych do tzw. nauk ścisłych) na podstawie jednego nieudanego przewidywania lub anomalii jest $w$ wielu przypadkach trudne, a może nawet niemożliwe. Jednak w rzeczywistości, wyrokiem wspólnoty uczonych, uwzględniającym przewagę danych, niektóre teorie (na przykład płaskiej ziemi, flogistonu czy heliocentryzm) zostały w końcu sfalsyfikowane. Fakt ten stawia demarkacjonistów w trudnym położeniu. $Z$ racji tego, że teoria flogistonu i teoria płaskiej Ziemi uległy miażdżącej falsyfikacji, muszą być one falsyfikowalne, a zatem naukowe. Czy takie sfalsyfikowane teorie są bardziej naukowe niż współczesne, odnoszące sukcesy teorie, które dzięki swojej elastyczności unikają falsyfikacji w obliczu pojedynczej anomalii? Czy teoria jawnie fałszywa jest bardziej naukowa niż taka, która ma dużą moc eksplanacyjną i może być prawdziwa? Laudan wykazał też, że niezmiernie łatwo sformułować (dowolne) przewidywanie, które - jeśli okaże się fałszywe - można uznać za rozstrzygający sprawdzian danej teorii. ${ }^{9}$ Astrologowie $\mathrm{i}$ frenologowie potrafią dokonać tego $\mathrm{z}$ równą łatwością, jak astronomowie i fizjologowie.

Sprzeczności takie nękały przedsięwzięcie demarkacjonistyczne od samego początku. Zważywszy na to, w opinii większości współcze-

\footnotetext{
${ }^{8}$ Imre LaKatos, „Falsyfikacja a metodologia naukowych programów badawczych”, w: Imre Lakatos, Pisma z filozofii nauk empirycznych, przeł. Wojciech Sady, Wydawnictwo Naukowe PWN, Warszawa 1995, s. 154-169 [3-169].

${ }^{9}$ Larry LaUdan, „Science at the Bar: Causes for Concern”, w: Michael Ruse (ed.), But Is It Science?, Prometheus Books, Buffalo, New York 1988, s. 354 [351-355].
} 
snych filozofów nauki problem: „Jakie metody odróżniają naukę od nienauki?" jest trudny do rozwiązania i nieinteresujący. Jakie bowiem znaczenie ma nazwa? Nie ma $\mathrm{z}$ pewnością statusu epistemicznego uzasadnienia czy autorytetu. Filozofowie nauki coraz bardziej zdają sobie sprawę, że w istocie nie chodzi o to, czy dana teoria jest naukowa, lecz czy jest prawdziwa lub potwierdzona empirycznie. Filozof Martin Eger podsumował całą tę sprawę następująco: ,argumenty demarkacyjne upadły. Filozofowie nauki przestali już się na nie powoływać. Nadal mogą cieszyć się one popularnością wśród laików, ale to inny świat”. ${ }^{10}$ Tak natomiast wyraził to Laudan: „Jeśli uprzemy się i zawierzymy zdrowemu rozsądkowi, to powinniśmy też wyrzucić z naszych słowników słowa takie jak «pseudonauka» [...] terminy te są jedynie pustymi wyrażeniami, mogącymi wyrażać tylko uczucia". ${ }^{11}$

\section{Argumenty demarkacyjne w debacie kreacjonizmu z ewolucjonizmem}

Pomimo odrzucenia kryteriów demarkacji przez filozofów nauki, nadal stosuje się je w różnych, ideologicznie nabrzmiałych debatach naukowych. Być może najbardziej dramatycznym tego przykładem jest debata kreacjonizmu z ewolucjonizmem. Obie strony sporu twierdzą, że teoria popierana przez stronę przeciwną odbiega od ustalonych kanonów metody naukowej. Tacy kreacjoniści jak Duane Gish uznają darwinowską teorię ewolucji za nienaukowy „metafizyczny program badawczy". Przyznawał to nawet sam Karl Popper, który kreacjonistą nie był. ${ }^{12}$ Obrońcy teorii ewolucji zazwyczaj używają takich samym taktyk w próbie całkowitego wykluczenia możliwości nie tylko sfor-

\footnotetext{
${ }^{10}$ Martin Eger, „A Tale of Two Controversies: Dissonance in the Theory and Practice of Rationality", Zygon 1988, vol. 23, s. 291-326.

${ }^{11}$ Laudan, „Zgon problemu demarkacji...”, s. 79.

${ }^{12}$ Karl Popper, „Darwinism as a Metaphysical Research Program”, w: Ruse (ed.), But Is It Science..., s. 145 [144-155].
} 
mułowania naukowej teorii stworzenia, ale i nauczania w amerykańskich publicznych szkołach średnich o kreacjonistycznych interpretacjach danych biologicznych.

W latach 1981-1982 w trakcie procesu w Arkansas, który dotyczył prawomocności nauczania „,nauki o stworzeniu”, filozof nauki, darwinista Michael Ruse przytoczył, jako podstawę wykluczania jakiejkolwiek teorii kreacjonistycznej ze szkół publicznych, pięć kryteriów demarkacji. Według Ruse'a, aby teoria była naukowa, musi (1) kierować się prawami przyrody; (2) wyjaśniać za pomocą praw przyrody; (3) być testowalna w empirycznym świecie; (4) utrzymywana niedogmatycznie oraz (5) falsyfikowalna. Ruse stwierdził, że kreacjonizm, który dopuszcza odwoływanie się do boskiego działania jako przyczyny niektórych wydarzeń w historii życia, nigdy nie spełni tych kryteriów. Kreacjonizm, podsumował Ruse, może być prawdziwy, ale nigdy nie będzie mieć statusu nauki. Przewodniczący składu sędziowskiego William Overton zgodził się z jego opinią i powołując się na podane przez niego kryteria demarkacji, wydał orzeczenie na korzyść American Civil Liberties Union (ACLU), na prośbę której Ruse wziął udział $\mathrm{w}$ procesie $\mathrm{w}$ roli biegłego.

Po zakończeniu procesu niektórzy filozofowie nauki, w tym Larry Laudan i Philip Quinn (którzy nie akceptują empirycznych twierdzeń kreacjonizmu), skrytykowali opinię Ruse'a. Uznali, że albo przedstawia on błędnie status problemu demarkacji, albo jest nieszczery. Obaj argumentowali, że kryteria Ruse'a nie mogą wskazać a priori, która teoria - kreacjonizm czy ewolucjonizm - ma status naukowy. Stwierdzili, że można to ustalić tylko dzięki konkretnym argumentom empirycznym, nie zaś metodologicznym.

*** (Przyp. red.) Oczywiście, dzięki konkretnym argumentom empirycznym można ustalić słuszność lub akceptowalność danej koncepcji, nie jej naukowość. Meyer zniekształcił tu poglądy krytyków Ruse’a. Laudan na przykład pisał tak: „Zamiast traktować kreacjonistów niewyraźnie i w całościowy sposób, sugerując, że to, co oni robią, jest krótko i węzłowato «nienaukowe» (co jest podwójnie niemądre, ponieważ tylko nieliczni autorzy mogą się zgodzić, co czyni jakąś czynność naukową), powinniśmy konfrontować ich twierdzenia bezpośrednio i pojedynczo pytając, jakie dane empiryczne i jakie argumenty można postawić za i przeciw każdemu z nich. Sednem sprawy nie jest to, czy kreacjonizm spełnia jakieś niemożliwe do 
Gruntowna analiza wykazała, że kryteria Ruse'a są problematyczne, zwłaszcza jeśli odniesie się je do debaty nad pochodzeniem biologicznym. Na przykład na tyle, na ile teorie kreacjonistyczna i ewolucjonistyczna mają charakter historyczny, czyli identyfikują przyczyny przeszłych zdarzeń, żadna z nich nie wyjaśnia wyłącznie za pomocą praw przyrody. Teoria wspólnego pochodzenia, która stanowi niewątpliwie główną tezę książki Darwina O powstawaniu gatunków (1859), nie wyjaśnia poprzez odniesienie do praw przyrody. Postuluje ona hipotetyczny wzorzec przeszłych zdarzeń, który - o ile jest prawdziwy - wyjaśnia różne obserwowane obecnie fakty. W rozdziale piątym O powstawaniu gatunków Darwin (1809-1882) mówi, że wspólnota pochodzenia to vera causa (rzeczywista przyczyna lub wyjaśnienie) zbioru różnorodnych obserwacji biologicznych. W darwinowskiej teorii wspólnego pochodzenia, jak zresztą w większości innych teorii historycznych, rolę eksplanacyjną odgrywają postulowane zdarzenia (lub wzorce), które uważa się za przyczyny innych zdarzeń (lub wzorców). Prawa przyrody takiej funkcji w niej nie pełnią. Jeśli zatem drugie kryterium demarkacji Ruse'a zastosuje się konsekwentnie, to zarówno teorię kreacjonistyczną, jak i darwinowską teorię wspólnego pochodzenia należałoby uznać za nienaukowe.

Podobne problemy wiążą się z pozostałymi kryteriami demarkacji Ruse'a. Do teorii mówiących o wydarzeniach przeszłych rzadko mają zastosowanie wyłącznie sprawdziany trafności przewidywań, wymagane przez Popperowskie kryterium falsyfikowalności. W teoriach dotyczących pochodzenia występują zazwyczaj twierdzenia o tym, co w przeszłości spowodowało zaistnienie obecnych cech Wszechświata. $\mathrm{W}$ ramach takich teorii z konieczności podejmuje się próby zidentyfikowania nieobserwowalnych, przeszłych przyczyn na podstawie aktualnie posiadanych wskazówek czy świadectw. Z perspektywy teorii re-

spełnienia i wysoce kontrowersyjne definicje tego, co znaczy, że jakaś koncepcja jest naukowa; rzeczywiste pytanie dotyczy tego, czy istniejące dane empiryczne mocniej przemawiają na rzecz teorii ewolucji niż na rzecz kreacjonizmu” (Larry LaUdan, „Science at the Bar - Causes for Concern”, w: Michael Ruse (ed.), But Is It Science? The Philosophical Question in the Creation/Evolution Controversy, Prometheus Books, Amherst, New York 1996, s. 354 [351-362]). 
konstruujących przeszłe wydarzenia metody testowania, które polegają na przewidywaniu nowych lub przyszłych zdarzeń, mają minimalne znaczenie. Ci, którzy uważają, że nieodzownym elementem testowania teorii jest formułowanie przewidywań, nie zaś porównywanie mocy eksplanacyjnej rywalizujących teorii, nie znajdą zbyt wielu znamion naukowości w żadnej teorii pochodzenia - ewolucyjnej lub dowolnej innej. ${ }^{13}$

Analiza innych kryteriów demarkacji, na jakie powołuje się Ruse, wykazuje, że one również nie pozwalają ustalić a priori, dlaczego teoria ewolucji jest naukowa, a kreacjonizm - nienaukowy. Dlatego w trakcie przemówienia na spotkaniu American Association for the Advancement of Science (AAAS) w 1993 roku Ruse wycofał się z poparcia dla kryterium demarkacji, przyznając, że darwinizm (podobnie jak kreacjonizm) ,przyjmuje pewne niemożliwe do udowodnienia założenia metafizyczne".

\section{Przyszlość problemu demarkacji}

U podstaw argumentów demarkacjonistycznych stosowanych w sporze o pochodzenie niemal z konieczności leży pozytywistyczna czy neopozytywistyczna (czyli Popperowska) koncepcja nauki. Dlatego też zaczęto się zastanawiać, czy nowe osiągnięcia w filozofii nauki mogłyby dostarczyć jakichś innych podstaw dla demarkacji. Niepozytywistyczne ujęcia racjonalności naukowej nie wydają się jednak dawać zbytniej nadziei na odnowienie programu poszukiwania kryterium demarkacji.

Filozofowie nauki Paul Thagard i Peter Lipton wykazali na przykład, że nie tylko w nauce, ale też w rozważaniach historycznych, filo-

\footnotetext{
${ }^{13}$ Por. Stephen C. Meyer, Of Clues and Causes: A Methodological Interpretation of Origin of Life Studies, rozprawa doktorska, Cambridge University 1990; Charles ТнахтоN, Walter Bradley, and Roger Olsen, The Mystery of Life's Origin, Lewis and Stanley, Dallas 1992.
} 
zoficznych i religijnych powszechnie występuje rodzaj rozumowania nazywany „wnioskowaniem do najlepszego wyjaśnienia”. ${ }^{14} \mathrm{Na}$ tej podstawie można wnosić, że wiedzy nie da się sklasyfikować na gruncie metodologicznym lub epistemologicznym tak łatwo, jak zakładali niegdyś zwolennicy kompartmentalizmu i demarkacjoniści. Dane empiryczne mogą mieć metafizyczne konsekwencje, zaś nieobserwowalne (a nawet metafizyczne) przedmioty mogą posłużyć do wyjaśniania obserwowalnych danych lub ich pochodzenia.

Nowsze badania nad metodami nauk historycznych wskazują, że podobieństwa metodologiczne i logiczne (zwłaszcza) między różnymi teoriami pochodzenia sięgają głęboko. Filozof biologii Elliott Sober argumentuje, że zarówno klasyczne kreacjonistyczne argumenty na rzecz projektu, jak i darwinowski argument na rzecz dziedziczenia z modyfikacją polegają na retrodykcyjnym wnioskowaniu do najlepszego wyjaśnienia. ${ }^{15}$ Inne prace $\mathrm{z}$ filozofii nauki wykazały, że kreacjonistyczne i ewolucjonistyczne programy badań próbują odpowiedzieć na typowe historyczne pytania; obydwa mogą mieć metafizyczne konsekwencje i podteksty; jeden i drugi używają typowych, historycznych form wnioskowania, wyjaśniania i sprawdzania. Oba też podlegają podobnym ograniczeniom epistemologicznym. Teorie stworzenia czy ,inteligentnego projektu” oraz naturalistyczne teorie ewolucji okazują się zatem, jak to określił jeden z autorów, „metodologicznie równoważne". Jeśli tylko przy rozstrzyganiu ich statusu poznawczego zastosuje się te same kryteria (pod warunkiem, że dla takich ocen przyjmie się kryteria neutralne metafizycznie), to oba typy teorii okazują się równie naukowe lub równie nienaukowe. ${ }^{16}$ Teorie te nie

\footnotetext{
${ }^{14}$ Por. Peter Lipton, Inference to the Best Explanation, Routledge, London 1991.

${ }^{15}$ Por. Elliott Sober, Philosophy of Biology, Oxford University Press, Oxford 1993. Por. też Michael J. BeHE, Czarna skrzynka Darwina. Biochemiczne wyzwanie dla ewolucjonizmu, przeł. Dariusz Sagan, Biblioteka Filozoficznych Aspektów Genezy, t. 4, Wydawnictwo MEGAS, Warszawa 2008.

${ }^{16}$ Por. Stephen C. Meyer, „The Methodological Equivalence of Design and Descent: Can There be a Scientific Theory of Creation?", w: J.P. Moreland (ed.), The Creation Hypothesis, InterVarsity Press, Downers Grove, Illinois1994, s. 67-112; Stephen C. MeYer, „The Na-
} 
muszą, oczywiście, być równoważne pod względem zdolności do wyjaśniania konkretnych danych empirycznych, ale omówienie tego problemu nie wchodzi w zakres niniejszego artykułu.

Stephen C. Meyer

\section{Bibliografia}

Ayala Francisco, w: John H. Campbell and J.W. Schoff (eds.), Creative Evolution!?, Jones and Bartlett, New York 1994.

BeHE Michael J., Czarna skrzynka Darwina. Biochemiczne wyzwanie dla ewolucjonizmu, przeł. Dariusz Sagan, Biblioteka Filozoficznych Aspektów Genezy, t. 4, Wydawnictwo MEGAS, Warszawa 2008.

Clouser Roy, The Myth of Religious Neutrality, Notre Dame University Press, Notre Dame, Indiana 1993.

Copleston Frederick, Historia filozofii. Od Benthama do Russella, t. VIII, przeł. Bohdan Chwedeńczuk, Instytut Wydawniczy PAX, Warszawa 1989.

Eger Martin, „A Tale of Two Controversies: Dissonance in the Theory and Practice of Rationality", Zygon 1988, vol. 23, s. 291-326.

Gillespie Neal, Charles Darwin and the Problem of Creation, University of Chicago Press, Chicago 1979.

Gingerich Owen, „The Galileo Affair”, Scientific American, August 1982, vol. 247, s. 133-143.

LAKATOS Imre, „Falsyfikacja a metodologia naukowych programów badawczych", w: Imre LaKatos, Pisma z filozofii nauk empirycznych, przeł. Wojciech Sady, Wydawnictwo Naukowe PWN, Warszawa 1995, s. 3-169.

ture of Historical Science and the Demarcation of Design and Descent", w: Jitse VAN DER MEER (ed.), Facets of Faith and Science: Interpreting God's Action in The World, vol. 4, University Press of America, Lanham, Maryland 1996, s. 91-130. 
LAUDAN Larry, „Science at the Bar: Causes for Concern”, w: Ruse (ed.), But Is It Science..., s. 351-355.

LAUDAN Larry, „Zgon problemu demarkacji”, przeł. Artur Koterski, w: Zbysław Muszyński (red.), Z badań nad prawdą, nauką i poznaniem, Realizm, Racjonalność, Relatywizm, t. 31, Wydawnictwo Uniwersytetu Marii Curie-Skłodowskiej, Lublin 1998, s. 63-79.

LIPTON Peter, Inference to the Best Explanation, Routledge, London 1991.

Mackay Donald M., „ «Complementarity» in Scientific and Theological Thinking”, Zygon 1974, vol. 9, s. 225-244.

Meyer Stephen C., „The Methodological Equivalence of Design and Descent: Can There be a Scientific Theory of Creation?", w: J.P. Moreland (ed.), The Creation Hypothesis, InterVarsity Press, Downers Grove, Illinois1994, s. 67112 .

Meyer Stephen C., ,The Nature of Historical Science and the Demarcation of Design and Descent", w: Jitse VAN DER MEer (ed.), Facets of Faith and Science: Interpreting God's Action in The World, vol. 4, University Press of America, Lanham, Maryland 1996, s. 91-130.

Meyer Stephen C., Of Clues and Causes: A Methodological Interpretation of Origin of Life Studies, rozprawa doktorska, Cambridge University 1990.

Moreland J.P., Christianity and the Nature of Science, Baker Books, Grand Rapids, Michigan 1989.

Plantinga Alvin, „Methodological Naturalism”, Origins and Design 1996, vol. 18 , no. 1 , s. $18-27$.

Plantinga Alvin, „When Faith and Reason Clash: Evolution and the Bible”, Christian Scholar's Review 1991, vol. 21, no. 1, s. 8-32.

Popper Karl, „Darwinism as a Metaphysical Research Program”, w: Michael Ruse (ed.), But Is It Science?, Prometheus Books, Buffalo, New York 1988, s. $144-155$.

SIMPSON George Gaylord, The Meaning of Evolution, Harvard University Press, Cambridge, Massachusetts 1967.

Sober Elliott, Philosophy of Biology, Oxford University Press, Oxford 1993. 
Thaxton Charles, Bradley Walter, and Olsen Roger, The Mystery of Life's Origin, Lewis and Stanley, Dallas 1992.

Van Till Howard, Young Davis, and Menninga Clarence, Science Held Hostage, InterVarsity Press, Downers Grove, Illinois 1988. 